\title{
Level of Revenue Development of Tourism Attraction Objects in The Negara Sub-District during the Covid-19 Pandemic
}

\author{
I Made Gata Sangasya Wiwekananda ${ }^{1}$, I Putu Ananda Citra ${ }^{1}$, A Sediyo Adi Nugraha ${ }^{1}$ \\ gatasangasya27@gmail.com, ananda.citra@undiksha.ac.id, adi.nugraha@undiksha.ac.id \\ ${ }^{1}$ Universitas Pendidikan Ganesha, Indonesia.
}

\begin{abstract}
Abstrak. This research was conducted on each tourism attraction in the Negara Subdistrict, with the aim of: 1) Describing the level of revenue development of each tourism attraction in the new normal period in the Negara Subdistrict, 2) Mapping the variation in the level of income development of each tourism attraction in the new normal period in the Negara Subdistrict. The methods used in this study are interviews and document recording. Sampling using purposive sampling technique with 5 respondents consisting of the Chairperson, Deputy Chairperson, Secretary, Treasurer and Members of the Tourism Awareness Group in each tourist attraction. This research is an exploratory study with qualitative data analysis. The results showed: : 1) The level of revenue development of tourism attraction revenues is highest in the Negara Subdistrict contained in Agrotourism Munduk Nangka, reaching Rp. 112,785,000 or equivalent to $84.00 \%$ of the total revenue of tourist attractions in the Negara Subdistrict, 2) Variations in the level of income development, two tourism attractions develop judging by the income, namely Baluk Rening Beach and Munduk Nangka Agrotourism.
\end{abstract}

Keywords:Tourism Development, Tourism Revenue, Covid-19 Pandemic

\section{Introduction}

Tourism has now become one of the largest industries in the world, and is a mainstay for earning foreign exchange in various countries. Tourism as an industry has the same role as a locomotive that cooperates with the carriages of economic activities that are directly or indirectly related to tourism. With the nature of the tourism industry, it will have an impact in various fields or a multiplier effect [2] . At the beginning of 2020 the world experienced a huge shock, the Covid-19 outbreak spread to all corners of the world, including Indonesia. The rapid spread of Covid-19 has caused various countries to issue policies such as implementing a State Lockdown, Flight Lockdown and other access, while in Indonesia the applicable policy is to carry out social distancing and physical distancing, in addition to suppressing the spread of the corona virus, the Indonesian government closed international flights [8] .

Policy setting in various countries is a big dilemma for tourism industry players, especially in Indonesia. Looking at the data in April 2020 shows, the total loss of the Indonesian tourism industry reached $\mathrm{Rp} 85.7$ trillion. Thousands of hotels and restaurants were forced to close as well as tour operators, resulting in the dismissal and furloughing of workers [5] . Seeing the collapse of the economy, the government finally responded by issuing 
a decree from the Minister of Health of the Republic of Indonesia Number HK.01.07/MENKES/328/2020 dated May 20, 2020 regarding guidelines for preventing and controlling Covid in office and industrial workplaces in supporting business continuity in a pandemic situation. With the issuance of this decree, Indonesia has officially reopened all sectors, including tourism.

The reopening of the tourism sector, Bali as the mecca of domestic tourism responded by issuing a circular letter from the Governor of Bali Number 3355 of 2020, on July 5, 2020, which marked the official reopening of tourism industry activities in Bali. Jembrana Regency is one of the regencies that is currently experiencing tourism development in the era of this new life order. Jembrana Regency has access to Gilimanuk Port which is already operating, as the entrance to the island of Bali, where on year-end holidays, tourist visits soar.

Based on the data presented in [6] , tourists who vacation to Bali on the end of 2020 holidays predominantly come by sea. Based on these data, Jembrana Regency greatly benefits from this situation, this is due to tourists who come from Gilimanuk Harbor, of course they will pass Jembrana Regency as the first Regency to be passed by tourists, so it is possible that tourists will visit tourism objects in the Regency. Jembrana, this is evidenced by the number of tourist visits to Jembrana Regency in 2020, as many as 86,606 visits [4]

Negara Sub-District, is the city center of Jembrana Regency, besides that in Negara Sub-District also has several very interesting tourist attractions to explore such as: Baluk Rening Beach, Munduk Nangka Agrotourism, Pebuahan Beach, Bugis Heritage Stage House, Jati Temple and Majapahit Temple. When compared to other sub-districts in Jembrana Regency, Negara sub-district is superior, this is because the tourism supporting facilities and infrastructure are more complete. Based on data from the (Badan Pusat Statistik Kabupaten Jembrana, 2021) the number of tourism supporting facilities in the Negara Sub-District, namely there are 81 restaurants, there are 21 accommodation/hotel businesses, there is one community health center, and one public hospital plus easy road access to the object tourism, so that it will attract tourists to travel first in the Negara Sub-District.

By allowing tourism activities to run, especially in the new normal era, of course there will be dynamics in tourism activities themselves. So that it becomes interesting to study more deeply, how is Level of Revenue Development of Tourism Attraction Objects in The Negara Sub-District during the Covid-19 Pandemic

\section{Methods}

This research is designed as exploratory research that describes Level of Revenue Development of Tourism Attraction Objects in The Negara Sub-District during the Covid-19 Pandemic which is viewed qualitatively with a spatial approach [7] . The design of this study was made to answer: how is the level of revenue development of tourism attraction objects in the Negara Sub-District during the Covid-19 Pandemic

The population in this study were all objects of tourist attraction in the Negara SubDistrict. The sample in this study used a purposive sampling technique with 5 respondents managing tourist attraction objects in each tourist attractions [9] . Data collection methods in this study are interviews, document recording, observation and documentation. The data used in this study include primary data and secondary data. Primary data is obtained directly from interviews and document recording. The primary data sought in this study are the level of revenue development of tourism attraction objects in the Negara Sub-District during the 
Covid-19 Pandemic data in the each tourist attraction object. where the data to be taken is data from a range of July 2020 to March 2021. While the secondary data in this study is data sourced from related agencies to support primary data.

The data analysis technique for problem formulation in this study can be processed using exploratory methods with qualitative analysis techniques. The data validation technique used is data triangulation, especially source triangulation, time triangulation and method triangulation [3]

\section{Ressult and Discussion}

Before heading to the results and discussion, first, the distribution of the distribution of tourist attraction objects in the Negara Sub-District will be presented.Where there are 6 objects of tourist attraction in the Negara Sub-District, more complete can be seen in table 1 below.

Table 1. Distribution of tourist attraction objects in the Negara Sub-District

\begin{tabular}{ccc}
\hline No & Tourist Attractions Object & Location \\
\hline 1 & Baluk Rening Beach & Baluk Village \\
2 & Munduk Nangka Agrotourism & Berangbang Village \\
3 & Pebuahan Beach & Banyubiru Village \\
4 & Bugis Heritage Stage House & Western Loloan Village \\
5 & Jati Temple & Pengambengan Village \\
6 & Majapahit Temple & Baluk Village \\
\hline
\end{tabular}

3.1 Level of Revenue Development of Tourism Attraction Objects in The Negara SubDistrict during the Covid-19 Pandemic

Table 2. Revenue Development of Tourism Attraction Objects in The Negara Sub-District during the

\begin{tabular}{|c|c|c|c|c|c|c|}
\hline Month & $\begin{array}{l}\text { Baluk } \\
\text { Rening } \\
\text { Beach }\end{array}$ & $\begin{array}{c}\text { Munduk } \\
\text { Nangka } \\
\text { Agrotourism }\end{array}$ & $\begin{array}{c}\text { Pebuahan } \\
\text { Beach }\end{array}$ & $\begin{array}{c}\text { Bugis } \\
\text { Heritage } \\
\text { Stage } \\
\text { House }\end{array}$ & $\begin{array}{c}\text { Jati } \\
\text { Temple }\end{array}$ & $\begin{array}{l}\text { Majapahit } \\
\text { Temple }\end{array}$ \\
\hline July & 0 & 0 & 0 & 0 & 0 & 0 \\
\hline Agust & 1.698 .000 & 0 & 0 & 0 & 0 & 0 \\
\hline September & 5.835 .000 & 48.040 .000 & 0 & 0 & 0 & 0 \\
\hline October & 1.652 .000 & 29.250 .000 & 0 & 0 & 0 & 0 \\
\hline November & 3.510 .000 & 12.240 .000 & 0 & 0 & 0 & 0 \\
\hline December & 2.329 .000 & 8.585 .000 & 0 & 0 & 0 & 0 \\
\hline January & 2.376 .000 & 9.765 .000 & 0 & 0 & 0 & 0 \\
\hline February & 0 & 2.950 .000 & 0 & 0 & 0 & 0 \\
\hline \multirow[t]{2}{*}{ Marct } & 4.072 .000 & 1.955 .000 & 0 & 0 & 0 & 0 \\
\hline & 21.473 .000 & 112.785 .000 & 0 & 0 & 0 & 0 \\
\hline
\end{tabular}


Source: Primary Data Analysis, 2021

\subsubsection{Baluk Rening Beach}

It is known that at Baluk Rening Beach the source of income comes from parking fees and vehicle security as well as retribution fees for street vendors along Baluk Rening beach. The cost of parking and security at Baluk Rening beach is only Rp. 1000, while the price for renting a place or retribution for street vendors is only Rp. 5000/day. Street vendors operating in the Baluk Rening Beach area only trade on Saturdays, Sundays and other holidays. Based on the results of interviews with street vendors who are in the Baluk Rening beach tourist area, explaining that during this new normal period, the retribution rate on Baluk Rening beach has not changed, it is still the same as in 2019 which only paid Rp. 5,000.

It can be seen that the largest revenue for Baluk Rening Beach occurred in September, with a total income in September of Rp. 5,835,000 this is because September is the month with the most tourist visits. In October, it can be seen that this month is the month with the least income in this new normal era, with an income of Rp. 1,652,000. In total, Baluk Rening Beach's income in this new normal era reached Rp. 21,473,000 sourced from tourist visits as many 19.312 and street vendor levies as much 432 . If you look more clearly at the data, it can be analyzed that the more number of tourist visits will greatly affect the income of the tourism object itself [1]

\subsubsection{Agrotorism Munduk Nangka}

The source of income for Munduk Nangka Agrotourism comes from entrance tickets, rides and motorcycle taxis. Where the price of admission for children is Rp. 5,000 and Adults Rp. 10,000, the rental price for rides ranges from Rp. 15,000 to Rp. 100,000 depending on the type of ride package, while motorcycle taxis are only Rp. 5,000. It is known that the trend of revenue development for Munduk Nangka Agrotourism continues to experience a very rapid decline. It can be seen that the highest income of Munduk Nangka Agrotourism occurred in September, where the income from the sale of entrance tickets reached Rp. 48,040,000. The high income of Agrotourism this month was caused by the booming number of visitors who came to travel, this happened because of the viral effect of Munduk Nangka Agrotourism on social media such as Instagram and Facebook. March is the month with the least income, which is only Rp. $1,955,000$, this is due to the drastic decline in tourist arrivals. If you look more clearly at the data, it can be analyzed that the more number of tourist visits will greatly affect the income of the tourism object itself [1]

\subsubsection{Pebuahan Beach}

Based on the results of interviews with respondents, it is known that at this time, the Pebuahan beach has not applied levies, either in the form of retribution for entering the Pebuahan beach, or levies for traders. This is based on the widespread abrasion and the unfinished handling of the abrasion on the beach. Based on this, the Banyubiru Village government took the decision not to apply the retribution, this aims to avoid misunderstandings between the Banyubiru Village government and the coastal community of Pebuahan, and to avoid conflicts as a result of the lack of optimal handling of abrasion on the Pebuahan beach. 


\subsubsection{Bugis Heritage Stage House}

From the table above, it can be seen that the Bugis Heritage Stage House has no income. this tourism object has not developed yet, this is due to a reduction in the number of houses on stilts, and the modernization of the shape and structure of houses on stilts. The house on stilts, which is identical to the one under the house, is now slowly losing its characteristics. From this, it causes a lack of asking tourists to visit, which of course has an impact on income, which automatically does not have income.

\subsubsection{Jati Temple}

Jati Temple as one of the spiritual tourism destinations in 2019 has income from parking fees and street vendors. The retribution fee for parking is divided into two types, motorbikes parking at a rate of Rp. 1,000 and car at a rate of Rp. 2,000 while the retribution fee for traders is Rp. 5,000. However, since it was reopened after the pandemic, the manager of Jati Temple has not applied a levy fee for parking and traders on the grounds that the community's economy is in crisis. So that in this new normal era, teak temples have no income.

\subsubsection{Majapahit Temple}

it is known that in 2019 the Majapahit Temple only imposed parking fees and street vendors during the religious ceremony of Majapahit temple, where tourist visits were very large. parking retribution fees are divided into two types, motorbikes with a parking fee of Rp. 2,000 and car at a cost of Rp. 3,000 while the retribution fee for street vendors is Rp. 5,000 . In this new normal era, the manager of Majapahit Temple did not apply retribution for tourists and street vendors. This is because the situation has not returned to normal, so the manager assumes at the time of the Majapahit Temple religious ceremony there will be no visits from tourists. From this assumption, the manager of Majapahit Temple decided to eliminate user fees for tourists and street vendors in this new normal era. So that Pura Majapahit in the new normal era has no income at all.

\section{Conclusion}

From the described previously, it can be concluded that two tourism attraction object are developing in terms of income, namely is Baluk Rening Beach and Agrotourism Munduk Nangka. It can be seen that the highest level of Revenue Development of Tourism Attraction Objects in The Negara Sub-District during the Covid-19 Pandemic is Agrotourism Munduk Nangka.

\section{References}

[1] Agung Ansyangga Pratama, A. A. G., \& Jember, I. M. (2020). Analisis Perkembangan Pariwisata di Wilayah Sarbagita Provinsi Bali. Jurnal Ekonomi Pembangunan Universitas Udayana, 9(3), 473-503.

[2] Arjana, I. G. B. (2016). Geografi Pariwisata dan Ekonomi Kreatif. PT RajaGrafindo Persada. 
[3] Bachri, B. S. (2010). Meyakinkan Validitas Data Melalui Triangulasi Pada Penelitian Kualitatif. Jurnal Teknologi Pendidikan, 10(1), 46-62.

[4] Badan Pusat Statistik Kabupaten Jembrana. (2021). Kabupaten Jembrana Dalam Angka 2021.

[5] Deutsche Welle Indonesia. (2020). BAGAIMANA SEKTOR PARIWISATA INDONESIA BERTAHAN DITENGAH PANDEMI CORONA. DW Indonesia. https://www.google.com/amp/s/amp.dw.com/id/bagaimana-pariwisata-indonesiabertahan-di-tengah-pandemi/a-54818132

[6] Maulana Firmansyah, L., \& Hidayatullah, T. (2021). Bali terhibur libur akhir tahun, okupansi hotel naik 50 persen. Lokadata.Id, 1.

[7] Mudjiyanto, B. (2018). Tipe Penelitian Eksploratif Komunikasi. Jurnal Studi Komunikasi Dan Media, 22(1), 65-74.

[8] Pratomo, H. (2020). FROM SOCIAL DISTANCE TO PHYSICAL DISTANCING : A CHALLENGE FOR EVALUATING PUBLIC HEALTH INTERVENTIONS AGAINST COVID-19. KEMAS: Jurnal Kesehatan Masyarakat Nasional (National Public Health Journal), 1(1), 60-63.

[9] Sugiyono. (2013). Metodelogi Penelitian Kuantitatif, Kualitatif, dan R\&D. ALFABETA. 